\title{
Isotype responses of mice to tetanus-toxoid preparations
}

\author{
Z. FARZAD* and K. JAMES†
}

MRC Reproductive Biology Unit, Centre for Reproductive Biology, 37 Chalmers Street, Edinburgh EH3 9EW and + Department of Surgery, University of Edinburgh Medical School, Teviot Place, Edinburgh EH8 $9 A G$

\begin{abstract}
Summary. The development of anti-tetanus antibodies in CBA/Ca and Balb/c mice immunised with two tetanus-toxoid preparations has been investigated by sensitive enzyme-linked immunoassays. These studies revealed the presence in both strains of mice of naturally occurring antibodies to tetanus toxoid. These were of the IgM, IgA and, to a lesser extent, the $\mathrm{IgG}_{3}$ isotypes. Differences in the responses of mice to the two toxoid preparations were noted; the purer preparation elicited a more rapid and pronounced response. Both strains of mice exhibited similar isotype responses.
\end{abstract}

\section{Introduction}

Because of marked differences in the biological activity of immunoglobulin $(\mathrm{Ig})$ subclasses and the current interest in development of monoclonal antibodies against bacterial antigens for diagnostic and therapeutic use, it was felt that detailed studies of Ig-isotype responses of mice to different tetanus toxoids should be undertaken to provide information in this important area. It is possible that tetanus-toxoid preparations of different degrees of purity might elicit quite different types of immune responses. Our studies were performed on mice because of the difficulty of obtaining human preimmunisation samples and because of the ease with which primary and secondary responses could be sequentially studied over a long time.

Responses to many antigens have been reported to be subclass restricted in the mouse (Torrigiani, 1972; Perlmutter et al., 1978; der Balion et al., 1980) and in man (Yount et al., 1968; Robboy et al., 1970; Carrel et al., 1972; van der Giessen et al., 1976). Furthermore, responses of man to diphtheria and tetanus toxoids have been variously reported to be predominantly $\mathrm{IgG}_{1}$ (Yount et al., 1968) or to involve all four subclasses (Carrel et al., 1972; Van Der Giessen and Groeneboer-Kempers, 1976). This point requires clarification and is important because subclass-restricted responses might dictate recovery from infection and the therapeutic effectiveness of passively transferred antibody.

In the present study the anti-tetanus Ig-isotypes

Received 2 Sep. 1985; revised version accepted 13 Dec. 1985.

* Correspondence should be sent to: Dr Zohreh Farzad, Jules Stein Eye Institute, UCLA School of Medicine, Los Angeles, CA 90024, USA. were assayed by a sensitive enzyme immunoassay (Farzad, 1985; Farzad et al., 1986) readily adaptable to the human system.

\section{Material and methods}

\section{Animals}

The experiments were performed on 10-12-week-old, male CBA/Ca or Balb/c mice. The CBA/Ca mice were bred from stock originally obtained from the MRC Laboratory Animal Centre, Carshalton, Surrey; the original Balb/c breeders were supplied by Olac Ltd, Bicester, Oxfordshire. The mice were housed under conventional conditions and fed ad libitum on Maintenance Diet No. 1 (Special Diet Service Ltd, Wilham, Essex).

\section{Antigens}

Two commercially available tetanus-toxoid preparations were used: (i) a standard vaccine preparation containing $40 \mathrm{LF}$ units and $0.3 \mathrm{mg}$ of protein/ml (Lot A53255, Wellcome Foundation Ltd, London); (ii) a purified tetanus-toxoid preparation containing $2250 \mathrm{LF}$ units and $4.6 \mathrm{mg}$ of protein/ml (Lot TAS-211, Connaught Laboratories Ltd, Willadale, Ontario, Canada). The latter was not approved for human use.

\section{Antisera}

Rabbit antisera specific for mouse $\operatorname{IgM}, \operatorname{IgA}, \operatorname{IgG}_{1}$, $I G_{2 a}, I g G_{2 b}$ and $I_{g G}$ were purchased from Litton Bionetics Inc., Kensington, MD, USA. The alkaline phosphatase-conjugated sheep anti-mouse immunoglobulin and goat anti-rabbit IgG were obtained from New England Nuclear, Boston, MA, USA, and Tago Inc., Burlingame, CA, USA. 


\section{Immunisation and bleeding schedules}

On day 0 , mice were given an intraperitoneal injection of either the Wellcome vaccine or the purified Connaught toxoid (10 $\mathrm{g}$ in saline). Identical booster injections were given subsequently on days 28 and 56 . Six mice from each treatment group were bled out on days $14,28,42,56$ and 70. Sera from mice that had not received injections served as pre-immunisation controls. Sera from individual mice were stored at $-20^{\circ} \mathrm{C}$.

\section{ELISA for anti-tetanus antibodies}

Two assays were developed to measure the responses of mice to tetanus toxoid; one permitted the measurement of the overall anti-tetanus-antibody levels, the other, a sandwich-enzyme immunoassay, allowed antibodies of particular isotypes to be detected. Both procedures were based upon the technique originally described by Engvall and Perlmann (1972). The development of these assays is described in detail elsewhere (Farzad, 1985).

ELISA-grade microtitration plates (Dynatech Laboratory, Billingshurst, Sussex) were used in both assays. Each well was coated with $100 \mu$ lof tetanus-toxoid solution ( 5 $\mu \mathrm{g}$ protein) and plates were then incubated at $37^{\circ} \mathrm{C}$ for $3 \mathrm{~h}$ followed by further incubation overnight at $4^{\circ} \mathrm{C}$. Excess fluid was removed from the wells by inverting and tapping the plates. Coated plates, sealed with clingfilm, were stored at $4 \mathrm{C}$ until required. Previous studies (Farzad et al., 1986) have shown the shelf life of these plates to be more than 1 year.

Just before use, the tetanus toxoid-coated plates were washed three times with physiological saline. In addition, plates were treated with $100 \mu \mathrm{l}$ of $0.06 \mathrm{M}$ phosphate buffer

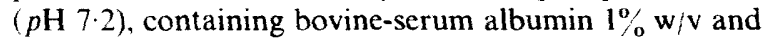
$0.15 \mathrm{M} \mathrm{NaCl}$, to prevent non-specific binding. After three more washes with PBS, plates were ready for use.

The overall antibody responses were measured as follows: doubling dilutions of the samples $(100 \mu \mathrm{l})$ were added to the antigen-coated plates which were incubated for $1 \mathrm{~h}$ at $37 \mathrm{C}$. Thereafter, unbound protein was removed by three washings of the plate with PBS and 100 $\mu \mathrm{l}$ of alkaline phosphatase-conjugated antibody (diluted 1 in 500 in PBS containing Tween 20 (Sigma) $0.05 \% \mathrm{v} / \mathrm{v}$; PBS-Tween) that reacted with all mouse-immunoglobulin isotypes, was added to the plates. After incubation at $37^{\circ} \mathrm{C}$ for $1 \mathrm{~h}$, plates were washed four times with PBSTween. The amount of enzyme bound was determined by addition of $100 \mu \mathrm{l}$ of $p$-nitrophenyl phosphate, disodium (Sigma) $1 \mathrm{mg} / \mathrm{ml}$ in $0.05 \mathrm{M}$ sodium-carbonate buffer $(p \mathrm{H}$ 9.8). After further incubation at $37^{\circ} \mathrm{C}$ for $1 \mathrm{~h}$, plates were read at $405 \mathrm{~nm}$ in a Multiscan Plate Reader (Dynatech, MA, USA).

The Sandwich-Enzyme-Immunoassay (SEI), used to determine the isotype of the anti-tetanus antibodies produced, was essentially similar to that described above except that it incorporated an additional step, which involved incubation of the plate with specific rabbit antisera to individual mouse-immunoglobulin isotypes before addition of the alkaline phosphatase-conjugated goat antibody to rabbit Ig. For this purpose, conjugate was diluted 1 in 2000 in PBS-Tween. In all assays the end point was the dilution giving a multiscan reading greater than $0 \cdot 1$.

In all tests, pooled sera from unimmunised and hyperimmunised mice were used as controls. Again, the optimum concentration of the various antibody reagents had been established in preliminary investigations (Farzad, 1985).

The antibody levels observed have been expressed as mean $\log _{2}$ titres together with the standard deviation from the mean.

\section{Results}

The responses of $\mathrm{CBA} / \mathrm{Ca}$ and $\mathrm{Balb} / \mathrm{c}$ mice to the
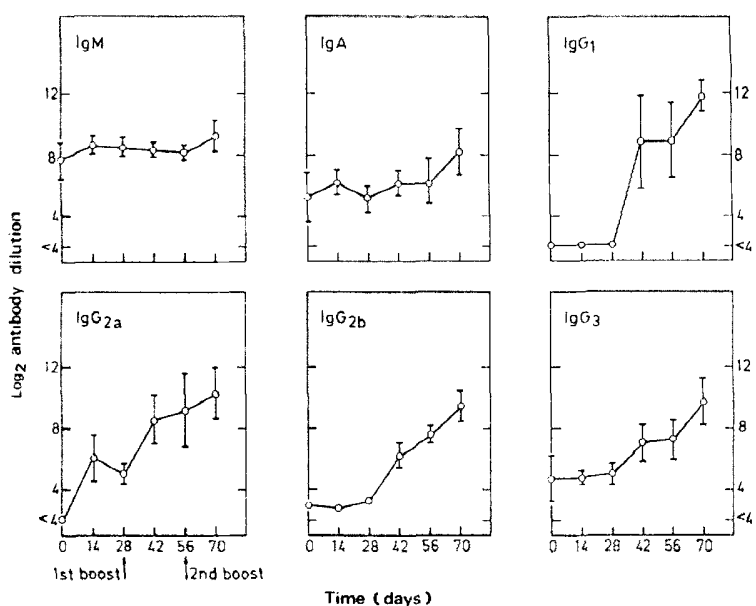

Fig. 1. Isotype responses after immunisation of $\mathrm{CBA} / \mathrm{Ca}$ mice with Wellcome toxoid. The standard deviations from the mean are shown.
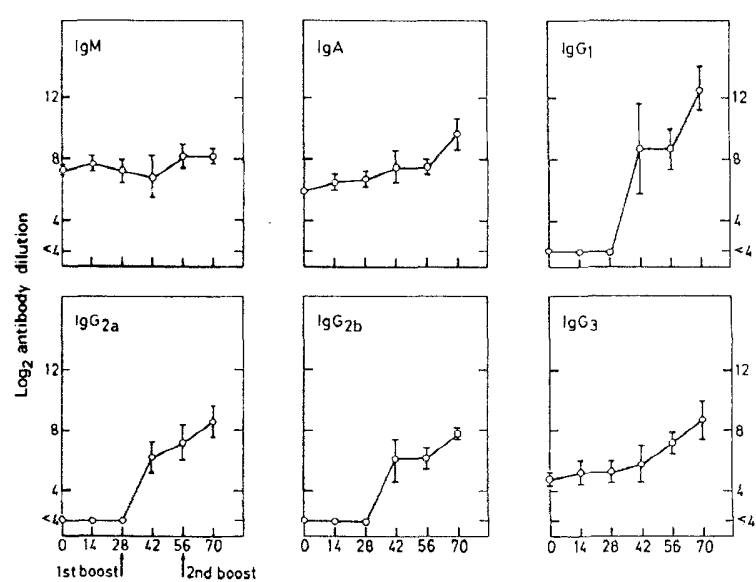

Time (days)

Fig. 2. Isotype responses after immunisation of Balb/c mice with Wellcome toxoid. The standard deviations from the mean are shown. 
Wellcome vaccine were almost identical (figs. 1 and 2). Sera from both strains of mice contained preexisting antibodies to the vaccine that were of the $\mathrm{IgM}, \mathrm{IgA}$ and, to a lesser extent, $\mathrm{IgG}_{3}$ isotypes. $\mathrm{Up}$ to 28 days after the initial injection of tetanus toxoid there was no discernible production of anti-tetanus antibody of any isotype other than the $\operatorname{IgG}_{2 \mathrm{a}}$ response noted in CBA/Ca mice. However, after the first boost, anti-tetanus antibodies of the $\mathrm{IgG}_{1}$, $\mathrm{IgG}_{2 \mathrm{a}}$ and $\mathrm{IgG}_{2 \mathrm{~b}}$ subclasses appeared and with subsequent boosting some of these, especially $\operatorname{IgG}_{1}$, continued to rise. The levels of $\operatorname{IgA}$ and $\operatorname{IgG}_{3}$ antitetanus antibodies also rose after boosting but less dramatically. In contrast, the titres of IgM antitetanus antibodies remained virtually unchanged. It should be noted that the pattern of response referred to above was consistent and was observed repeatedly in CBA/Ca mice.

The two toxoid preparations elicited different responses in the same strain (Balb/c) of mice. There was a more rapid response to the purer Connaught preparation than to the crude Wellcome toxoid (figs. 2 and 3). Again, appreciable levels of $\operatorname{IgG}_{1}$ and $\mathrm{IgG}_{2 \mathrm{a}}$ anti-tetanus antibodies were detected before boosting (fig. 3). Furthermore, the responses of the different IgG subclasses other than $\operatorname{IgG}_{2 b}$ were more pronounced with the Connaught toxoid than with the Wellcome toxoid (figs. 2 and 3).

To examine the cross-reactivity of the Ig-isotype antibodies elicited by the different toxoids, the reactivity of certain sera from immunised Balb/c mice was compared on plates coated with either the Wellcome or Connaught preparations. These studies revealed similar patterns of response irrespective of the toxoid preparations used to coat the
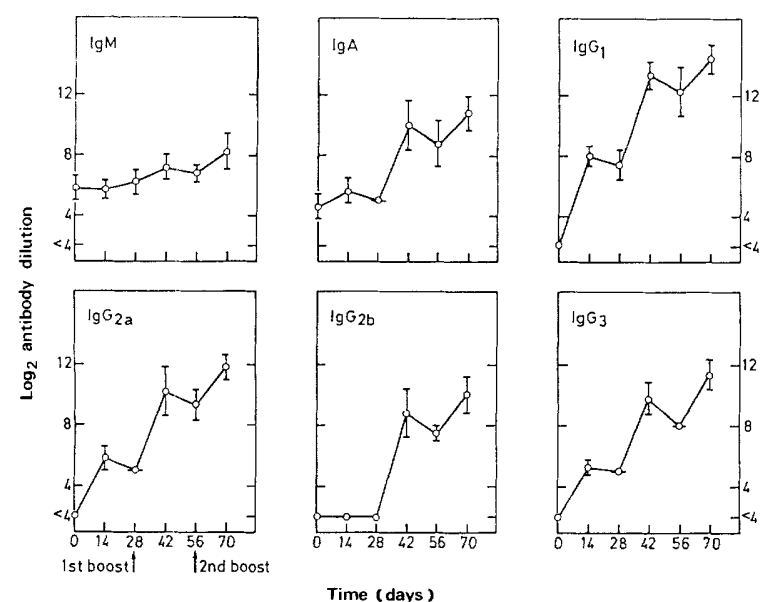

Fig. 3. Isotype responses after immunisation of $\mathrm{Balb} / \mathrm{c}$ mice with Connaught toxoid. The standard deviations from the mean are shown.
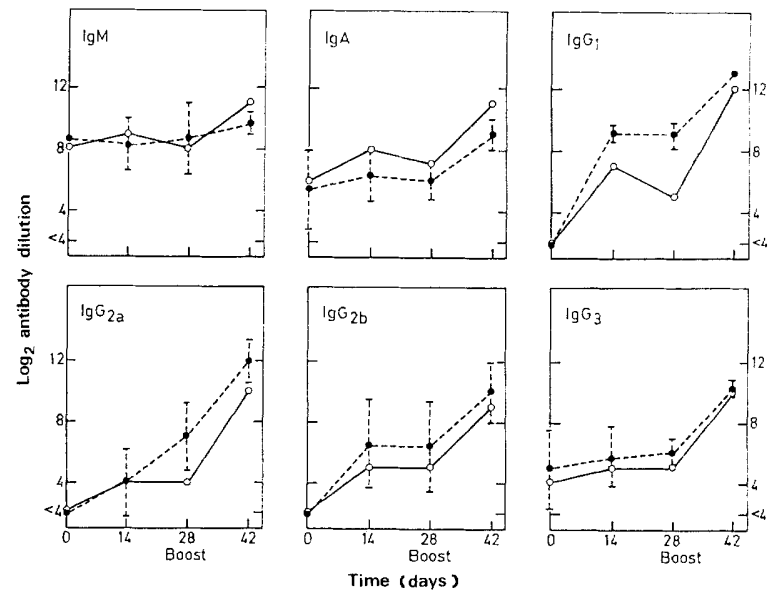

Fig. 4. Isotype responses after immunisation of Balb/c mice with Connaught toxoid. Assays were performed on microtitration plates coated with: Connaught toxoid, -..toxoid $\mathrm{O}-\mathrm{O}$.
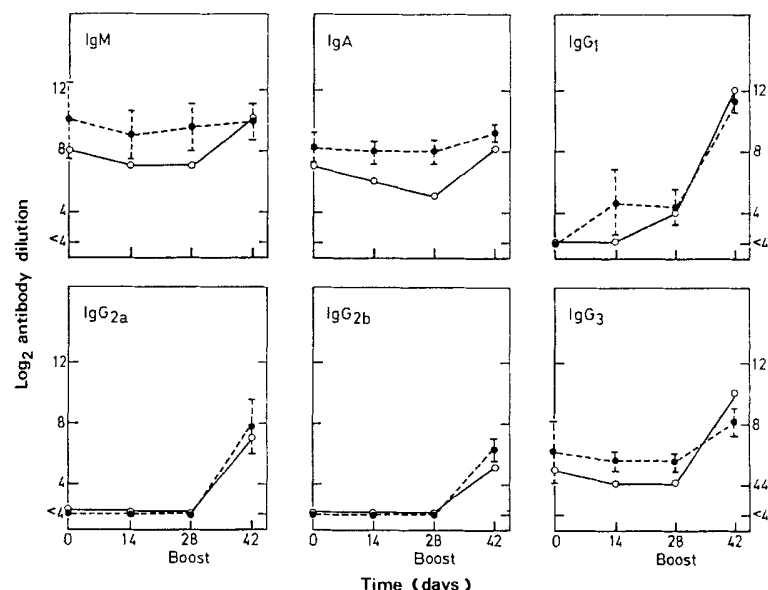

Fig. 5. Isotype responses after immunisation of Balb/c mice with Wellcome toxoid. Assays were performed on microtitration plates coated with: Wellcome toxoid, ----- $\bullet$; Connaught toxoid, $\mathrm{O}-\mathrm{O}$.

ELISA plates (figs. 4 and 5). This indicated that the differences previously noted (figs. 2 and 3 ) were determined by the antigens used for immunisation rather than by the assay procedure. These results also confirmed the reproducibility of the assay system used in the present studies.

\section{Discussion}

The demonstration of "naturally acquired" antibodies to tetanus toxoid in mice of both strains is interesting. Because the majority of people are immunised against tetanus, few studies are avail- 
able with regard to pre-existing antibodies in man, although before the discovery of tetanus toxoid, Tenbroeck and Bauer (1923) reported the detection of antitoxin antibodies in the blood of one-third of a group of inhabitants of Peking, China, whose stools contained tetanus bacilli. A more recent serological study in unvaccinated men and animals in the Galapagos Islands by Veronesi et al. (1983) found various titres of antibodies. No reports are available, however, on the Ig-isotypes of these antibodies.

The finding that the isotype distribution of preexisting antibodies was different from that of the response following immunisation is of some interest. The natural antibodies were found in both strains of mice against both crude and pure toxoids, indicating that the antibodies were to tetanus toxoid and not a contaminating protein. The most probable explanation for the existence of naturally occurring antibodies to tetanus is that the spores of Clostridium tetani are swallowed by man and mice and stimulate a response. Indeed, it has recently been suggested that the oral route might provide an effective vaccination route for man against tetanus (Veronesi et al., 1983). This route might preferentially stimulate $\operatorname{IgM}$ and $\operatorname{IgA}$ antibodies. On the other hand, determinants might be shared among tetanus toxoid and other macromolecules, or intestinal organisms such as other species of Clostridium.

The findings that naturally occurring antibodies were of $\operatorname{IgM}$ and $\operatorname{IgA}$ isotypes and that responses of mice to both tetanus-toxoid preparations were largely in the IgG isotypes are in agreement with those of Ershler et al. (1982), who found that mice gave a poor primary response and that on boosting antibody isotype was mainly IgG. It seems possible that natural existing $\operatorname{IgM}$ and $\operatorname{IgA}$ antibodies may play a role in inhibiting the subsequent response of these isotypes.

The response in man to tetanus toxoid has been variously reported as being predominantly $\operatorname{IgG}_{1}$

\section{REFERENCES}

Boyd J E, Hastings I, Farzad Z, James K, McClelland D B L 1984 Experiences in the production of human monoclonal antibodies to tetanus toxoid. Developments in Biological Standardization 57:93-98.

Carrel S, Morell A, Skvaril F, Barandun S 1972 Human tetanus antibodies: isolation and characterization with special reference to the IgG subclasses. FEBS Letters 19:305-307.

Der Balion G P, Slack J, Clevinger B L, Bazin H, Davie J M 1980 Subclass restriction of murine antibodies. III. Antigens that stimulate $\mathrm{IgG}_{3}$ in mice stimulate $\mathrm{IgG}_{2 \mathrm{c}}$ in rats. Journal of Experimental Medicine 152:209--218.
(Yount et al., 1968; Van Der Giessen and Groeneboer-Kempers, 1976) and unrestricted (Carrel et al., 1972). In this study, the responses of two strains of mice to the Wellcome vaccine showed no obvious isotype restriction. Antibodies were detected in all IgG subclasses except $\operatorname{IgG}_{2 b}$ immediately after primary challenge with pure (Connaught) tetanus toxoid.

The absence of a primary response to Wellcome vaccine observed in our study might result from the crude nature of the preparation. Nevertheless, despite the crude nature of Wellcome tetanus toxoid, differences were not found in the abilities of the two preparations to bind antibody, suggesting that responses to contaminating proteins are weak. Previous studies on the physiochemical properties of the two tetanus-toxoid preparations revealed that Connaught tetanus toxoid was less heterogeneous and had a much higher toxoid activity than the Wellcome vaccine (Farzad, 1985). Whether or not this pure preparation is more effective at eliciting anti-tetanus antibodies in man or produces fewer or weaker side reactions on booster immunisation remains to be established. Wellcome vaccine is known to cause allergic reactions in some men (Farzad, 1985).

These studies, which were undertaken as a prelude to similar investigations in man, suggest that measurement of Ig-isotypes might be important in establishing the immune status of individuals receiving different vaccine preparations. They also suggest that these techniques are suitable for measurement of anti-tetanus antibody of specific isotype and are useful in measuring and producing immunoglobulin preparations derived either by immunisation of blood donors or by the monoclonal procedure (Boyd et al., 1984; Farzad, 1985).

This study was supported by the Medical Research Council, UK.

Engvall E, Perlmann P 1972 Enzyme-linked immunosorbent assay, Elisa. III. Quantitation of specific antibodies by enzyme-labeled anti-immunoglobulin in antigen-coated tubes. Journal of Immunology 109:129-135.

Ershler W B, Moore A L, Hacker M P 1982 Specific in vivo and in vitro antibody response to tetanus toxoid immunization. Clinical Experimental Immunology 49:552-558.

Farzad Z 1985 Studies on anti-tetanus antibodies. Ph.D thesis, University of Edinburgh.

Farzad Z, James K, McClelland D B L 1986 Measurement of human and mouse anti-tetanus antibodies and isotype analysis by ELISA. Journal of Immunological Methods 87:119-125. 
Perlmutter R M, Hansburg D, Briles D E, Nicolotti R A, Davie J M 1978 Subclass restriction of murine anti-carbohydrate antibodies. Journal of Immunology 121:566-572.

Robboy S J, Lewis E J, Schur P H, Colman R W 1970 Circulating anticoagulants to Factor VIII: Immunochemical studies and clinical response to Factor VIII concentrates. American Journal of Medicine 49:742-752.

Tenbroeck C, Bauer J H 1923 Studies on the relation of tetanus bacilli in the digestive tract to tetanus antitoxin in the blood. Journal of Experimental Medicine 37:479-489.

Torrigiani G 1972 Quantitative estimation of antibody in the immunoglobulin-classes of the mouse. II. Thymic dependence of the different classes. Journal of Immunology 108:161-164.

Van Der Giessen M, Groeneboer-Kempers O 1976 The sub- classes of human IgG antibodies against tetanus toxoid. Clinical Experimental Immunology 25:117-121.

Van Der Giessen M, Homan W L, Kernebeek G, Van Aalberse R C, Dieges P H 1976 Subclass typing of IgG antibodies formed by grass pollen-allergic patients during immunotherapy. International Archives of Allergy and Applied Immunology 50:625-640.

Veronesi R, et al. 1983 Naturally acquired antibodies to tetanus toxin in humans and animals from the Galapagos Islands. Journal of Infectious Diseases 147:308-311.

Yount W J, Dorner M M, Kunkel H G, Kabat E A 1968 Studies on human antibodies. VI. Selective variations in subgroup composition and genetic markers. Journal of Experimental Medicine 127:633-646. 